\title{
投入土砂堆積形状予測モデルにおけるパラメー夕設定と 流れ場への適合性
}

\section{1.はじめに}

バージによる土砂投入工法は，効率な施工から大規模 な埋立工事や護岸基礎部の築造工事に多く採用されてき ている.この投入工法は，施工管理の点から投入土砂の 堆積形状に関する事前把握，施工層厚を均一化するため の適正な投入位置，さらには流れ場における投入土砂の 堆積形状予測等に問題を残している．特に関空第 2 期工 事のような大規模水域における埋立工事を円滑に実施す るためには，施工管理計画上，上記の問題を解決された 投入土砂の堆積形状に関する予測手法の確立が不可欠で あると言えよう。

松見ら（1998）は，既にバージ直投による堆積土砂の 船幅方向中央断面形状が投入水深の増加に伴って「一山 型 $\rightarrow$ 台形円錐 $\rightarrow$ 二山型 $\rightarrow$ 平型」への変化パターンを評価 できる堆積土砂形状に関する予測モデルを確率論に基づ いて開発してきた. 本予測モデルは, 投入土砂の水深方 向への散乱現象に関してマルコフ・チェーンを適用して いることから，施工水深の変化に対して汎用性をもって いる。 また，松見ら (1998) は本予測モデルの全開式バー ジによる投入土砂堆積形状に対する適合性を模型実験よ り明らかにすると共に，現地に対して十分に適合するこ とを報告した。しかしながら，対象土砂別に予測モデル に含まれる確率パラメー夕を水理模型実験によって予め 決定する必要があり，現地に対して汎用的に適用するた めにはパラメー夕の設定方法を確立する必要がある。

本研究は，まず松見ら（1998）が提案した予測モデル の底開式バージに対する適合性を水理模型実験より検討 し，ついで全開式バージを対象に予測モデルに含まれる 確率パラメー夕について水理実験を行って検討すると共 に，これまでに報告されてきたバージの直投による模 型・現地実験結果および計算結果をとりまとめて, 確率 パラメータの設定方法について検討したものである。ま た本研究では，現地土砂投入時に特に問題とされている 流れ場に対する本予測モデルの適合性についても水理実

* 正会員 工修 東亜建設工業 $($ 株)大阪支店

** 正会員 水修 東西建設工業(株)技術研究所

*** 正会員 工博 東亜建設工業(株)土木本部設計部

**** 正会員 工博 鳥取大学助教授 工学部社会開発システム工学科
太田正規 ${ }^{*}$ - 荒井 清* - 五明美智男** 矢内栄二 $* * * \cdot$ 松見吉晴 $* * * *$

験より検討を行った。

\section{2. 底開式バージに対する予測モデルの適合性}

\section{（1）実験の概要}

実験に使用した水槽は, 長さ $4 \mathrm{~m} \times$ 幅 $3.8 \mathrm{~m} \times$ 高さ $2 \mathrm{~m}$ の三次元水槽である. 底開式バージの模型は図一 1 に示 すアクリル樹脂製 $120 \mathrm{~cm} \times 48.4 \mathrm{~cm} \times 40 \mathrm{~cm}$ で， $3200 \mathrm{~m}^{3}$ 積バージの $1 / 50$ 縮尺模型を使用した.ホッパ部の開閉は 手動によって行われ，ホッパ扉（図中黒く塗りつぶした 部分）はホッパ部の自重と投入土砂重量によって瞬時に 開放される。ホッパの最大開扉角度および開扉幅は, そ れぞれ 90 度と $24 \mathrm{~cm}$ である.バージ船模型の設置高さ は, 原型の満載時の喫水 $4.7 \mathrm{~m}$ を考慮して $9.4 \mathrm{~cm}$ で一 定とした。

水槽底面には, 軟弱底面を想定して厚さ $100 \mathrm{~mm}$ の平

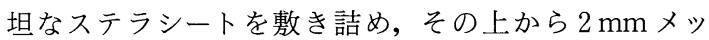
シュの厚さ約 $1 \mathrm{~mm}$ のナイロンシートでステラシートを 覆った。このステラシートの堆積土砂荷重による沈下量 $\delta l$ は，水中での載荷荷重実験（松見ら，1998）より次の 実験式を得ている

$$
\delta_{l}=4.3-3.9 \exp (-0.04 \mathrm{~W})-0.91 \exp (-0.52 \mathrm{~W})
$$

ここに，W は載荷荷重である.

実験は一点一回投入で, 投入水深が $60 \mathrm{~cm}$ 及び $80 \mathrm{~cm}$

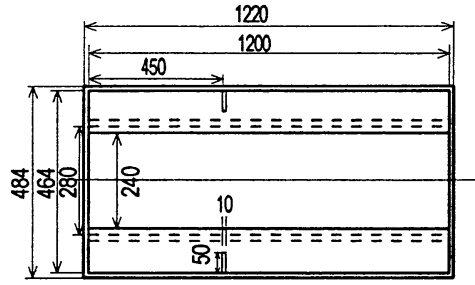

Unit:cm
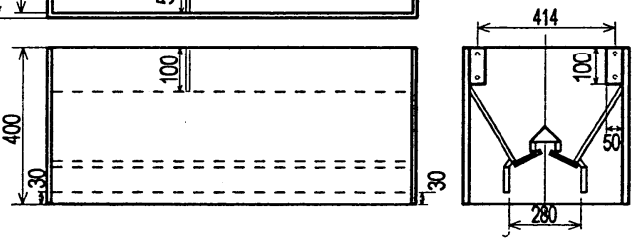

図-1＼cjkstart底開式バージ模型 

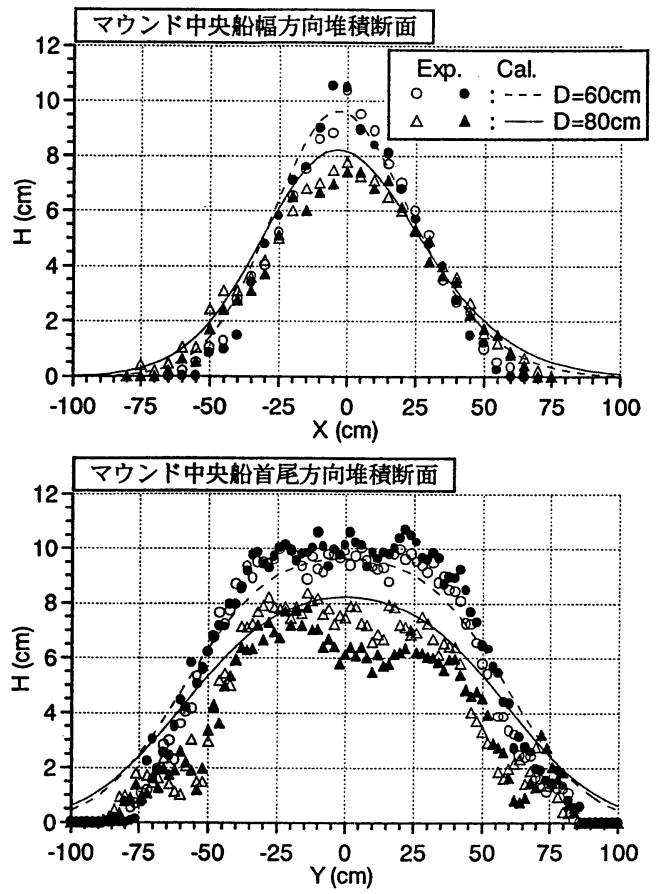

図一2 底開式バージの実験結果と予測結果の比較

の 2 種類について各水深毎に 2 回行った. 投入土砂量は $0.114 \mathrm{~m}^{3}$ で一定とした. 使用した土砂は, 2〜50 mm のコ ンクリート用採石で, 中央粒径は約 $14 \mathrm{~mm}$ である. 堆積 マウンド形状の測定は, レーザ変位計を用いて船首尾方 向に $2 \mathrm{~cm}$ 間隔，船幅方向には $5 \mathrm{~cm}$ 間隔で行った.

\section{(2) 検証結果}

予測モデルに含まれる土砂の散乱移動に関する標準偏 差と平均値については, 最小投入水深 $D=60 \mathrm{~cm}$ の実験 結果より推定し, $D=80 \mathrm{~cm}$ の投入水深に対する本予測 モデルの適合性を検証する，なお，計算における水深方 向の区間長を $10 \mathrm{~cm}$ (一定) にしている.

図一2 は軟弱底面に対する底開式バージによる一点一 回投入時のマウンド中央船幅および船首尾方向の堆積断 面形状について, 実験結果と予測計算結果を比較したも のである. 図中破線で示す $D=60 \mathrm{~cm}$ の結果より推定さ れた標準偏差および平均值を用いた $D=80 \mathrm{~cm}$ の投入水 深における実線で示す予測結果は, 船幅方向および船首 尾方向共に実験結果をほぼ再現しており, 本予測モデル の底開式バージによる直投土砂堆積形状に対する適合性 が認められる。

\section{3. 予測モデルのパラメータの設定に関する検 討}

\section{（1）確率パラメータに関する次元解析}

本予測モデルは, 図一 3 に示すように水深方向に等分
割した各区間毎の土砂の散乱分布特性が同一の平均值 $m$ および標準偏差 $\sigma$ をもつ正規分布でそれぞれ近似で きること（松見ら，1992）に基づいて，各水深区間にお ける土砂の到達位置に関する確率分布の算定にマルコ フ・チェーンを適用した方法である。このように各水深 区間で算定された船幅方向および船首尾方向におけるそ れぞれの土砂の到達位置に関する確率分布の積から各区 間毎の土砂の平面的な到達位置に確率分布が得られ, 最 終的にバージの積載土砂体積（空隙を含む）との積によ り堆積形状を予測するものである。本予測モデルに含ま れる未知パラメー夕は，水深を等分割した水深区間にお ける土砂の散乱分布特性に関する平均値 $m$ および標準 偏差 $\sigma$ の 2 種類だけであり,これらの確率パラメータの 設定はこれまで水理模型実験より対象土砂粒径毎に行わ れてきた。したがって本研究では，予測モデルの汎用性 を拡張するために確率パラメー夕の設定方法について次 元解析より検討を行う.

各水深区間毎の土砂の散乱分布特性に関する平均值 $m$ および標準偏差 $\sigma$ は, 次式のような変数によって定ま る関数で与えられるものと考えられる。なお，ここでは 標準偏差 $\sigma$ についてのみ示すが, 平均值 $m$ についても次 式と同様である.

$$
f\left(\sigma, \Delta z, d_{50}, \rho_{s}, w_{f}, D, \rho, \mu, g, U\right)=0
$$

ここに,

$\Delta z$ : 予測モデルの水深区間長, $d_{50}$ ：土砂の中央粒径 $\rho_{s}:$ 土砂の密度, $w_{f}:$ 土砂の平均沈降速度

$D:$ 投入水深, $\rho:$ 流体の密度

$\mu:$ 流体の分子粘性係数, $g:$ 重力加速度

$U:$ 流体場の主流速

ここで, $\Delta z$ は予測計算モデルにおいて $10 \mathrm{~cm} \sim 100 \mathrm{~cm}$ の間で, 例えば $10 \mathrm{~cm}, 20 \mathrm{~cm}$ と一定值として取り扱われ るために式（2）ょり除くと，式（2）は $\pi$ 定理により

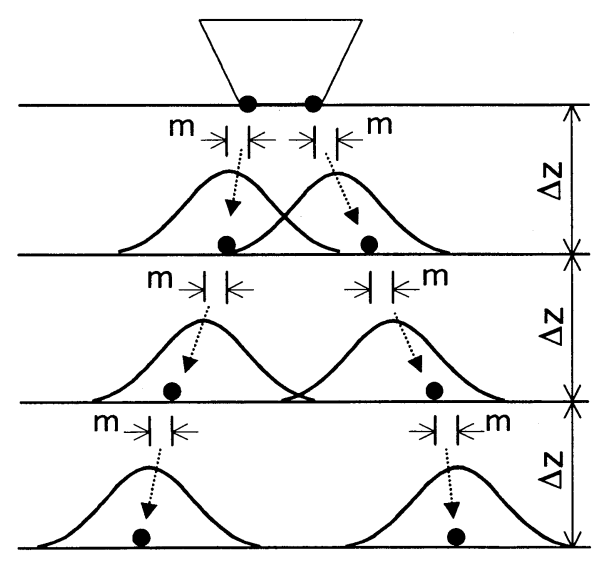

図一－土砂の落下散乱に関する確率モデル 


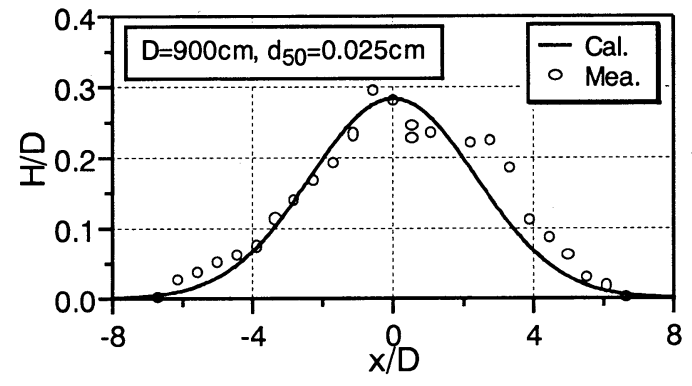

(a) 堤らの現地観測結果（1975）

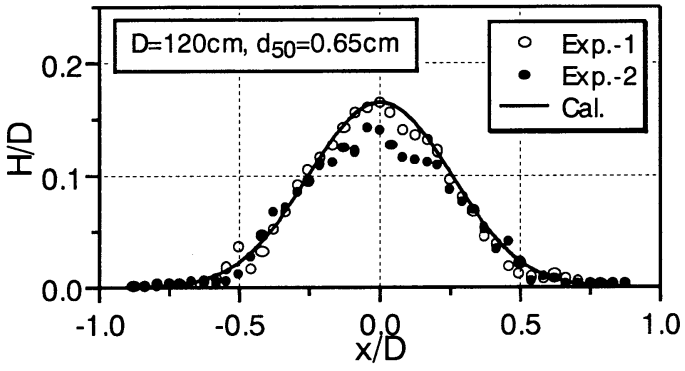

(c) 矢内らの実験結果 (1997)

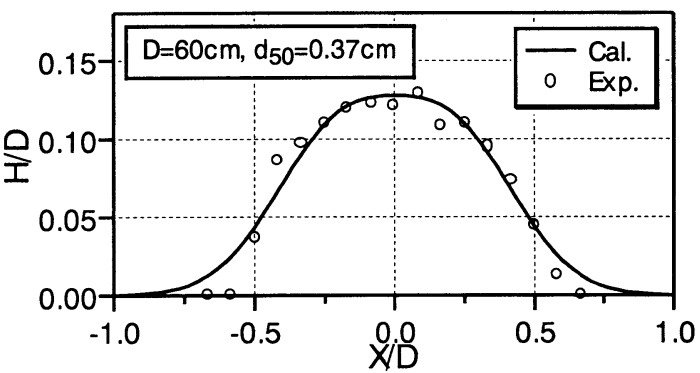

(b) 本研究の結果

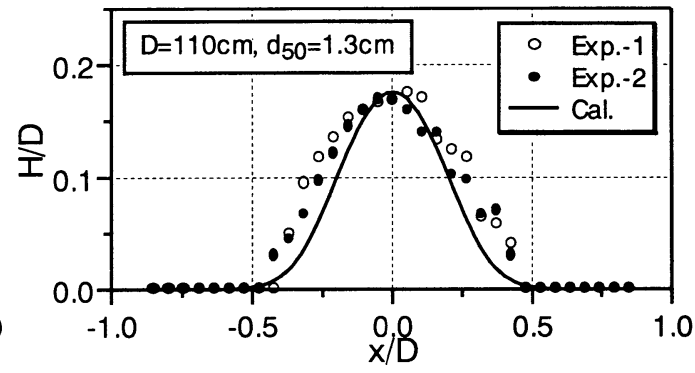

(d) 矢内らの実験結果 (1998)

図-4 実験結果と計算結果の比較図

次式のような無次元量で与えられる.

$$
f\left(\frac{\sigma}{d_{50}}, \frac{\rho_{s}}{\rho}, \frac{w_{f} d_{50}}{\nu}, \frac{D}{d_{50}}, \frac{w_{f}}{\sqrt{g d_{50}}}, \frac{U}{w_{f}}\right)=0
$$

式（3）において，各水深区間毎の土砂の散乱特性を 表す標準偏差を $\sigma / d_{50}$ と $d_{50} / D$ の積で表すと, 標準偏差に 関して次の関係式が得られる。

$$
\frac{\sigma}{D}=f\left(\frac{\sigma_{s}}{\rho}, \frac{w_{f} d_{50}}{\nu}, \frac{w_{f}}{\sqrt{g d_{50}}}, \frac{U}{w_{f}}\right)
$$

ここで, 土砂の平均沈降速度を $w_{f}=\sqrt{\left(\rho_{s} / \rho-1\right) g d_{50}}$ とす ると, 式 (4)の右辺カッコ内第 3 項の土砂の沈降フルー ド数は

$$
\frac{w_{f}}{\sqrt{g d_{50}}}=\frac{\sqrt{\left(\rho_{s} / \rho-1\right) g d_{50}}}{\sqrt{g d_{50}}}=\sqrt{\left(\rho_{s} / \rho-1\right)}
$$

と整理できる．本研究では土砂の密度をほぼ一定なもの を対象とすることから, 沈降フルード数は一定值になる. また, 式 (4)における $\rho_{s} / \rho$ の值も一定となる.したがっ て, 各水深区間毎の土砂の散乱特性を規定する標準偏差

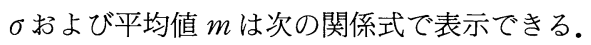

$$
\frac{\sigma}{D}, \frac{m}{D}=f\left(\frac{w_{f} d_{50}}{\nu}, \frac{U}{w_{f}}\right)
$$

以上のことから，投入土砂の堆積形状に関する予測モ デルにおける土砂の落下散乱に関する確率パラメータ は，土砂の沈降速度に関する沈降レイノルズ数および流 れ場の主流速と投入水深によって強く支配されることが 明らかになった。なお， $\sigma$ な゙粒子自身の乱れによる場
合の算定式については， $w_{f} d_{50} / \nu<1 \sim 10$ における林・大 橋の解 $(1980), w_{f} d_{50} / \nu<300 \sim 400$ における吉川らの解 (1977）がある.

本研究では, これまでに報告してきた模型実験および 現地実験結果について各投入水深における確率パラメー 夕を再計算すると共に, 異なった土砂粒径を対象として $3000 \mathrm{~m}^{3}$ 積み全開式バージの縮尺 $1 / 36$ の模型による投 入実験を新たに行った. 実験に使用した投入土砂は粒径 $5 \mathrm{~mm}$ 以下の中央粒径 $d_{50}=3.7 \mathrm{~mm}$ のコンクリート用砕 石で, 1 回当たりの投入土砂量は $38000 \mathrm{~cm}^{3}$ で一定とし た. 投入水深は $60 \mathrm{~cm}$ とし, 堆積形状はレーザー変位計 により計測した. 図一 4 は, それぞれの投入水深および土 砂粒径に対する従来の現地実験および模型実験結果も含 めて新たに推定された確率パラメータを用いて計算され た堆積マウンド船幅方向中央断面形状に対する予測結果 と実験結果を比較して示したものである.これらの結果 は, 全て流れがない状態 $(U=0)$ での結果である. 本子 測モデルは現地および模型実験共によく再現しているこ とがわかる。

\section{（2）確率パラメータに関する実験式}

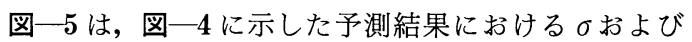
$m$ の各水深区間長毎の值と粒径レイノルズ数の関係を 示したものである。これらの結果より， $\sigma / D$ および $m / D$ と $w_{f} d_{50} / \nu$ の間には粒径レイノルズ数の $-1 / 4$ 乗に比例 する次式の関係式が存在することが推定できる. 


$$
\begin{aligned}
& \frac{\sigma}{D}=C_{1 \_} \sigma\left(\frac{w_{f} d_{50}}{\nu}\right)^{-1 / 4}+C_{2} \sigma \\
& \frac{m}{D}=C_{1 \_} m\left(\frac{w_{f} d_{50}}{\nu}\right)^{-1 / 4}+C_{2}{ }_{-} m
\end{aligned}
$$

式 $(7)$ に含まれる係数 $C_{1} \_\sigma, C_{2} \sigma, C_{1} m$ および $C_{2} m$ は図-4の結果より表一 1 に示す值が得られた.これらの 值を用いて予測計算に打ける各水深区間長毎 $(\Delta z=$ $10 \sim 100 \mathrm{~cm}$ の間を $10 \mathrm{~cm}$ 間隔毎）に $\sigma / D$ および $m / D$ と $w_{f} d_{50} / \nu$ の関係を示したのが図一6 と図一7である.これ らの図には荒井ら (1999) の現地投入結果 $(D=14 \mathrm{~m}$, $\left.d_{50}=6 \mathrm{~cm}, w_{f} d_{50} / \nu \fallingdotseq 48000\right)$ も示している. $\sigma / D$ に関する 関係式は現地の結果をよく再現しているが, $m / D$ の関係 式は水深区間長 $\Delta z$ を大きくとると粒径レイノルズ数が 高い領域で再現性に問題を残している.土砂粒径が小さ いほど落下に伴う分散性が大きくなるため $\sigma / D$ およ゙ $m / D$ 共に大きな値になることを示している.

土砂投入に関する施工管理計画に当たつては, 式 ( 7 ) および表一1より投入水深と投入土砂の中央粒径に対す る確率パラメータが決定され, 投入土砂の堆積マウンド 形状が予測計算できる。図一 8 は, 先の現地投入結果 $\left(D=14 \mathrm{~m}, d_{50}=6 \mathrm{~cm}\right)$ に対して, $\Delta z=100 \mathrm{~cm}$ における 標準偏差および平均值より予測された堆積マウンド中央 船幅方向の堆積断面形状に関する検証結果を示したもの
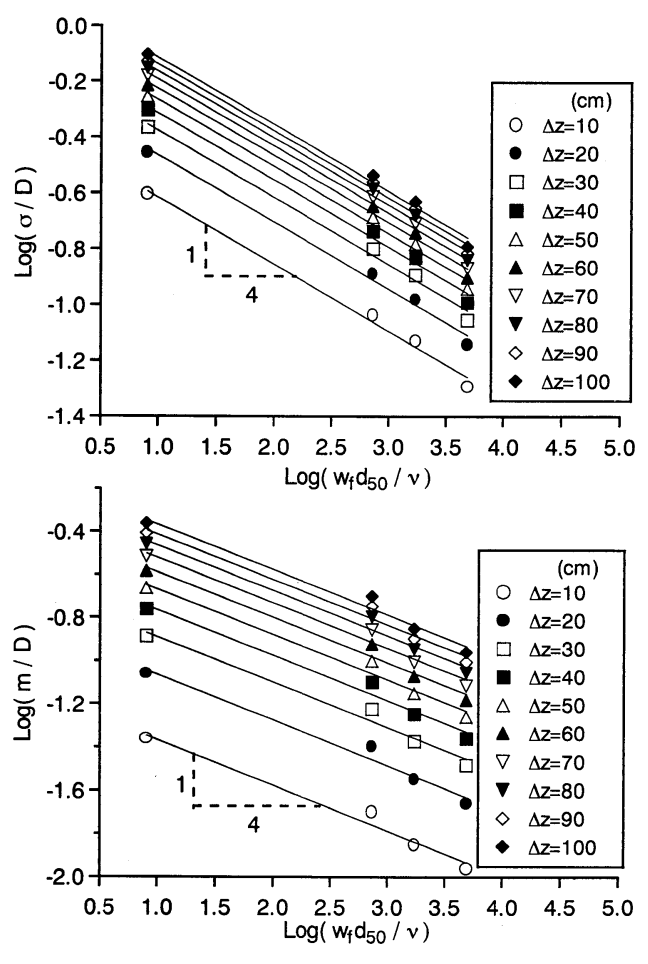

図一5 $\sigma / D$ および $m / D$ と $w_{f} d_{50} / \nu$ の関係
表-1 確率パラメー夕設定式の係数

\begin{tabular}{c|c|c|c|c}
\hline$\Delta z(\mathrm{~cm})$ & $C_{1_{-} \sigma}$ & $C_{2} \sigma$ & $C_{1_{-}} m$ & $C_{2_{-}} m$ \\
\hline 10 & 0.4022 & 0.0104 & 0.0693 & 0.0031 \\
20 & 0.5688 & 0.0147 & 0.1385 & 0.0062 \\
30 & 0.6966 & 0.0180 & 0.2078 & 0.0093 \\
40 & 0.8044 & 0.0208 & 0.2771 & 0.0124 \\
50 & 0.8993 & 0.0233 & 0.3463 & 0.0155 \\
60 & 0.9851 & 0.0255 & 0.4156 & 0.0186 \\
70 & 1.0641 & 0.0275 & 0.4849 & 0.0217 \\
80 & 1.1375 & 0.0294 & 0.5542 & 0.0248 \\
90 & 1.2065 & 0.0312 & 0.6234 & 0.0279 \\
100 & 1.2718 & 0.0329 & 0.6927 & 0.0310 \\
\hline
\end{tabular}

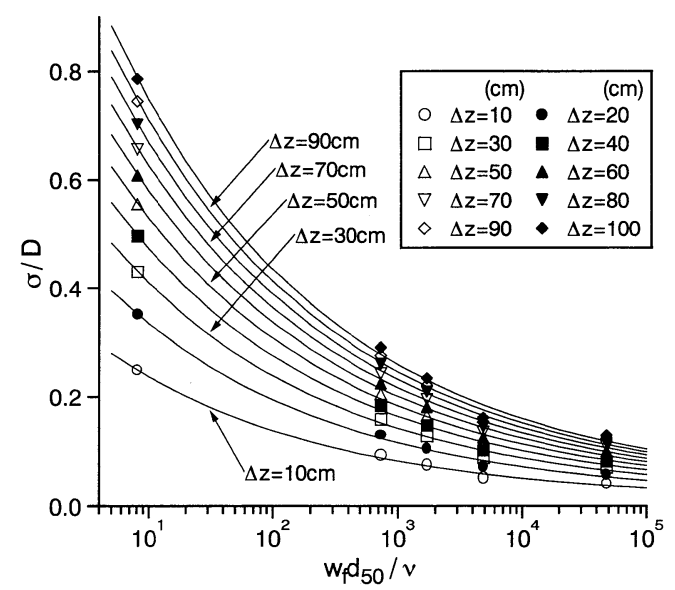

図一6 各水深区間長における $\sigma / D$ の設定式

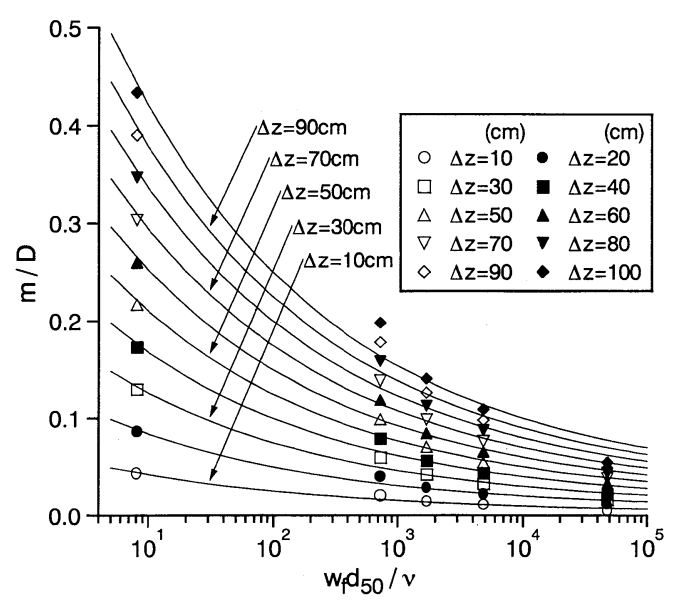

図一7 各水深区間長における $m / D$ の設定式

である.図中の実線は現地結果より推定した確率パラ メー夕によるもので, 破線が式 ( 7 ) 抢よび表一1による 予測結果である. 予測結果は, 平均值 $m$ の值が大きく見 積もられた結果, 特に二山のギャップを低く評価するが, マウンド高さおよび拡がり幅はほぼ再現できている. 


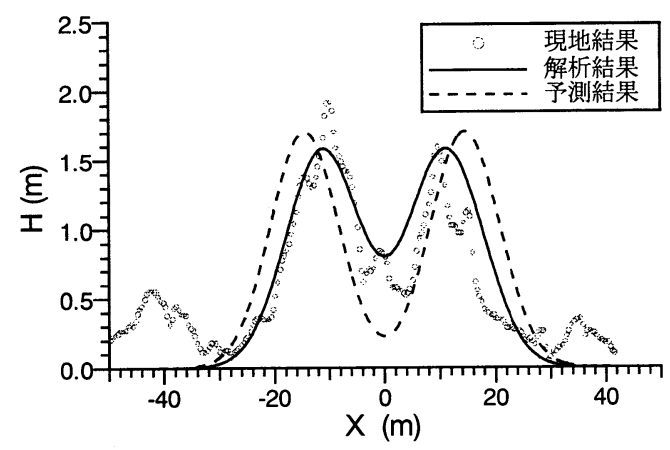

図一8＼cjkstart現地結果に対する検証結果

\section{4. 流れ場に対する適合性}

流れ場における直投土砂の堆積形状に関する本予測モ デルの適合性に関しては,先に示した $1 / 36$ 縮尺の全開式 バージ模型を用いた水路幅 $50 \mathrm{~cm}$ の 2 次元水路による 実験より検討を行った。全開式バージの船首尾長が 45 $\mathrm{cm}$ であるため, 投入土砂の船首尾方向への移動は水路 側壁によって拘束されることから，実験は船幅方向への 土砂の落下散乱に及ぼす流れの影響に関する二次元実験 である. 本実験では, 水深 $55 \mathrm{~cm}$ 一定で流速を $7 \mathrm{~cm} / \mathrm{s}$ と $14 \mathrm{~cm} / \mathrm{s}$ の 2 種類と静水場について各々 2 回の投入実験 を行った。

小田・重松ら（1995）は個別要素法と MAC 法を併用し た数值実験より，流れ場を沈降する粒子群の重心位置が 流れ方向に流速に線形的に比例して移動することを明ら かにしている. 予測計算では，この研究結果に基づいて 予測モデルの確率パラメータの平均值 $\mathrm{m}$ に対して流速 による流下方向への移動分 $m^{\prime}$ を付加すること $\left(m+m^{\prime}\right)$ により，流れの影響を確率パラメー夕の平均值の変化と 考慮することした，なお，流下方向への移動分は計算上 の水深区間長 $\Delta z$ を沈降する時間と流速との積で与える ことにした。 また予測計算では，小田・重松ら（1995） が指摘している流速場での堆積断面の上流と下流におけ る非対称性を再現させるため, $\Delta z=5 \mathrm{~cm}$ に設定して投 入土砂の着底から堆積終了までを離散的に水深 $55 \mathrm{~cm}$, $50 \mathrm{~cm}$ および $45 \mathrm{~cm}$ における堆積形状の和で最終的なマ ウンド形状を算定している。

図一9は，流れ場における直投土砂の堆積形状(船幅方 向断面）について実験結果と計算結果を示したものであ る. 本予測モデルは, 確率パラメータの平均值 $m$ に流速 による移動分の付加および土砂の堆積過程を離散的に扱 うことにより, 上流と下流側での非対称性も含めて堆積 形状をよく再現する。
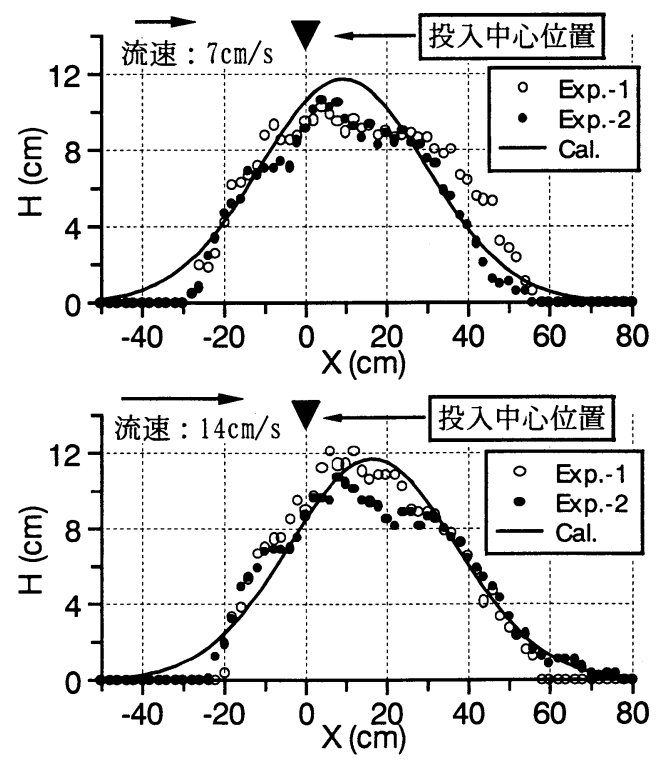

目一9 流れ場の検証結果

\section{5. まとぬ}

本研究では, 直投土砂の堆積形状に関する予測モデル の底開式バージへの適合性，流れ場に対する適合性を確 認すると共に，全開式バージの土砂を対象とした確率パ ラメータの設定法を明らかにした。 今後は底開式バージ の確率パラメー夕設定法における係数を検討していく.

\section{参 考 文 献}

荒井 清・太田正規・五明美智男・矢内栄二・松見吉晴 (1999)： 底開・全開バージによる土砂投入形状の現地比較実験, 海洋 開発論文集，第 15 巻, pp. 225-229.

小田一紀・重松孝昌・菅野 寛 (1995)：粒子群の沈降・分散挙 動に及ぽす流れの影響に関する数值実験, 海岸工学論文集, 第 42 巻, pp. 1271-1275.

堤 一高・内河栄作・半沢秀郎・島 正憲 (1975)：軟弱地盤上 に投下された砂の状況調查一大型土捨船による砂投下実 験一，土と基礎，Vol. 23，No. 11，pp. 57-63.

林 泰造・大橋正和（1980）：流体中を沈下する粒子の乱流特性 について，第 24 回水理講演会論文集，pp. 7-12.

松見吉晴・荒井 清・太田正規・矢内栄二・増田 稔 (1998)：軟 弱底面上に投入した土砂の堆積形状とその予測, 海岸工学論 文集，第 45 巻，pp. 891-895

松見吉晴・泉 一幸 (1992)：底開式バージによる投入捨石群の 堆積形状に関する予測モデル, 海岸工学論文集, 第 39 巻, pp 966-970.

矢内栄二・横堀浩一・松見吉晴 (1997)：トレミー管および全開 バージによる投入土砂の堆積形状, 海洋開発論文集, Vol. 13, pp. 369-373.

吉川秀夫・福岡捷二・吉川勝秀 (1977)：流体と固体粒子の相互 作用に関する研究，土木学会論文集，No. 260，pp. 89-100. 